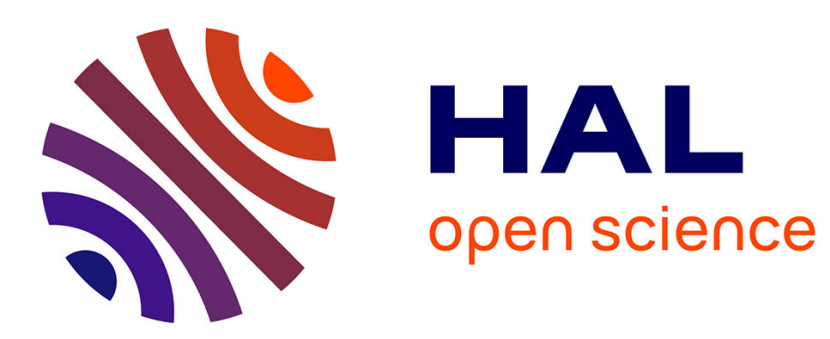

\title{
Convergence on sustainable lifestyles? Mechanisms of change and resistance in a french allotment
}

Géraldine Farges

\section{To cite this version:}

Géraldine Farges. Convergence on sustainable lifestyles? Mechanisms of change and resistance in a french allotment. 2012. hal-02803966

\section{HAL Id: hal-02803966 https://hal.inrae.fr/hal-02803966}

Preprint submitted on 5 Jun 2020

HAL is a multi-disciplinary open access archive for the deposit and dissemination of scientific research documents, whether they are published or not. The documents may come from teaching and research institutions in France or abroad, or from public or private research centers.
L'archive ouverte pluridisciplinaire HAL, est destinée au dépôt et à la diffusion de documents scientifiques de niveau recherche, publiés ou non, émanant des établissements d'enseignement et de recherche français ou étrangers, des laboratoires publics ou privés. 


\title{
Convergence on Sustainable Lifestyles? Mechanisms of Change and Resistance in a French Allotment
}

\author{
Géraldine Farges
}

Septembre 2012

Working Paper ALISS 2012-07

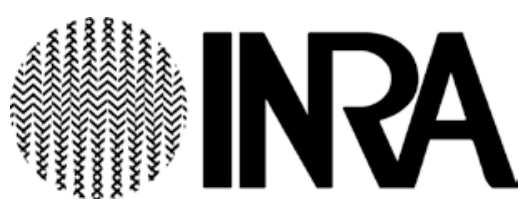

INRA UR 1303 ALISS

65, Bd de Brandebourg

94202 I vry-sur-Seine Cedex

France

http://www.paris. inra.fr/aliss 


\section{SOLAL}

Sociologie de l'alimentation

\section{Convergence on Sustainable Lifestyles? Mechanisms of Change and Resistance in a French Allotment ${ }^{1}$}

\section{Farges Géraldine}

INRA, UR 1303 ALISS, F-94200 Ivry-sur-Seine, France

Abstract: This paper aims to contribute to understanding convergence on sustainable lifestyles in relation to recent governmental promotion of sustainability. We analyse the effects of inducement to pro-environmental practices in amateur gardeners on an allotment, a group of plots of land collectively managed in an urban context. We examine the conditions in which allotment gardeners integrate practices and norms on sustainability. Through a one-year ethnographic research project consisting of observations and repeat interviews with gardeners, we demonstrate that while they adopt new cultural techniques for their plots, the meanings of their gardening practices differ, as do their relationships with the environment. We identify three ideal types of gardeners and show that the diffusion of pro-environmental practices is not systematically related to shared concerns and that the meaning of practices can be interpreted differently by policymakers and lay individuals.

${ }^{1}$ This article has been submitted to Sociologia Ruralis for consideration of publication.

This research was funded by a postdoctoral fellowship from the region lle de France (programme DIM ASTREA). Results were presented at the team seminar of food sociology, INRA ALISS UR 1303 (J une 2012, Paris), at the XIII World Congress of International Rural Sociology (July-August 2012, Lisbon), and at the interim meeting of Sociology of Consumption Network of the European Sociological Association (September 2012, Berlin). The author thanks participants for their comments. The author would also like to thank Séverine Gojard, Florence Weber, François Jeannet, Sophie Dubuisson-Quellier, Marie Plessz, Ana Perrin-Hérédia and Anaïs Malié for their contribution to different stages of this research. 


\section{Introduction}

Governmental and ecological organisations address collective challenges to sustainability by promoting citizens' education in new behaviours and initiating a new type of rationality (Rumpala 2009). Citizen-consumers are considered willing to modify their behaviour if alternatives are available. Small acts are praised as the beginning of larger societal change (Halkier 1999). However, many limits to this approach have been pointed out. It has been argued that consumption decisions are influenced by factors such as convenience or social relations, and that even wellinformed citizens may not change their habits. What is more, sociologists who adopt a practice theory framework describe the processes of changing practices and demonstrate that pro-environmental intentions do not necessarily precede proenvironmental actions (Hargreaves 2011). They consider how practices are performed by practitioners, how they stabilise and diffuse, and how they are challenged by other practices (Warde 2005). However, an analysis of how lifestyles might change also needs to know if the diffusion of new practices parallels the diffusion of new social norms. The diffusion of social norms as more or less explicit prescriptions for individual conformity would generate more radical changes in everyday life because social norms define what is to be valued in all kinds of social action. Social norms would suppose the emergence of concern, or even reflexivity, on sustainability. Thus, in this paper, following a Weberian approach (Weber 1976), we hypothesise that 
individuals performing similar actions may not imbue them with similar meanings and, further, that convergence on sustainable lifestyles is limited if the implementation of practices is not integrated with an environmental consciousness.

To examine how individuals integrate practices and norms on sustainability, we investigated the local implementation of a national policy on amateur gardening. In France, the Ecophyto 2018 plan that emerged from the Environment Round Table ${ }^{1}$ in 2007 aims to reduce the use of pesticides by 50 per cent in agriculture and amateur gardening. This plan is at the heart of an initiative titled "Other ways of gardening" implemented to provide information through leaflets and a web site on recommendations for gardening practices. Although this initiative is relevant to all amateur gardeners, our analysis more precisely focuses on kitchen gardening within the framework of allotment gardens. These are groups of plots of land individually cultivated but collectively managed by associations or public authorities. Since the beginning of the 1990s, the French Ministry for Environment has encouraged their development to preserve biodiversity, promote social integration, and provide education on environment (Monédiaire 1999). The main organisations of allotments are partners with government in implementing its environmental policy. In this paper, we question the extent to which allotment gardeners follow these new proenvironmental guidelines and attempt to understand the meanings they attribute to both their former and current kitchen gardening practices. By studying their food consumption practices, we also attempt to see if the introduction of changes in gardening practices has generated new practices and concerns outside the garden. 
In the first section, we develop inducements for French gardeners to converge on proenvironmental practices by examining current changes within allotments. In the second section, we present our empirical material from a one-year ethnographic research project in an allotment. The third section expounds on the results of our analysis. We distinguish three ideal types of gardeners by how they use their plots in relation to their views on sustainability and describe the different degrees to which gardeners integrate norms and practices of sustainability.

\section{“Ecologizing” the garden}

Gardening, food growing, and environment

Traditionally, maintaining an ornamental garden with flowers and green lawns is different from cultivating a kitchen garden (Dubost 1997). Kitchen gardening is part of a popular lifestyle where food growing is a domestic activity and constitutes a counter-measure to economic hardship, above all for workers with rural origins (Grignon and Grignon 1980; Pinçon 1986). Despite its economic interest for general households, kitchen gardening is not only a survival of peasantry. It is also a testimony to the moral value of amateur gardeners who derive self-esteem from their garden and its production (Caillavet and Nichèle 1999; Gojard and Weber 1995; Pluvinage and Weber 1993; Weber 1998). Kitchen gardening remains a popular activity that underwent social diffusion in the second half of the $20^{\text {th }}$ century with the 
emergence of detached houses with private gardens and related home-centred activities (Campbell 2005; Constantine 1981; Gelber 1997).

Kitchen gardening can be part of a sustainable way of life. Justin L. Schupp and Jeff S. Sharp (2012) investigated home food gardening in the United States and found that individuals participating in activities related to local food systems are highly likely to be growing their own fruit and vegetables. However, gardeners make important use of chemical inputs. Manuel Pluvinage and Florence Weber (1992) noted that gardeners remained reluctant to use them because they felt committed to the "law of nature”. During the $20^{\text {th }}$ century, the use of pesticides and chemical fertilizers by gardeners grew parallel with the development of private lawns and ornamental gardens. In France, non-agricultural use of chemical inputs is responsible for around 10 per cent of the total national consumption. There are approximately 14 million gardeners in France, and 60 per cent of these make use of chemical products, praising their ease of use and efficiency ${ }^{2}$. They do not consider their own practice as harmful for health or environment, especially in comparison with the quantities used in agricultural industries (Barrault 2009; Dobré 2002). Paul Robbins and Julie T. Sharp (2003) point out that high-income and high-education-level gardeners, although particularly aware of environmental issues, use chemical products for aesthetic purposes. Susan Clayton (2007) questions the extent to which the home landscape is considered part of nature and notes that, although nature is important, the yard is not clearly seen as part of the ecosystem. 


\section{Kitchen gardening in an allotment}

In the French context, allotments can be controlled by local, national, or corporate associations and local or regional public authorities. Allotments are usually closed to the public. Gardeners pay annual fees to use a plot and are required to obey internal rules. Allotments were initiated in the $19^{\text {th }}$ century in parallel with industrialisation and urbanisation to provide poor urban populations with food and to maintain social order (Cabedoce and Pierson 1996; Constantine 1981; Dubost 1997; Weber 1998). They were rediscovered at the end of the $20^{\text {th }}$ century in parallel with the emergence of environmental issues ${ }^{3}$. New allotments have been created that are more standardised and more often controlled by local public authorities than by local firms or local associations. Furthermore, a new educated urban population is becoming involved in allotments. Frédérick Guyon (2008), in discussing allotments in the French city of Strasbourg, points out that employees now form the biggest occupational category of gardeners with professionals and managers also increasingly interested ${ }^{4}$. Standardised ready-to-serve sites (in aesthetics and equipment) are the most applied for, and gardeners are increasingly seeking family and leisure activities (Guyon 2008).

The importance of allotments in achieving sustainability has been indicated in previous studies. They contribute to local sustainability (Holland 2004) and affect the way communities think about food, environment, and health (Hale et al. 2011). Community gardens have been associated with increased consumption of fruit and 
vegetables (Alaimo et al. 2008), increased social capital (Alaimo et al. 2010), and improvements in physical and mental health (Wakefield et al. 2007). Some analyses suggest that the use of chemical inputs is important in allotments, although few studies have been dedicated to these particular areas (Girardin 1994; Pluvinage and Weber 1992). Since 2007, French national allotment associations have acted as government ecology policy partners in implementing rules to convert their gardeners to pro-environmental gardening. In one example, the French Allotment and Leisure Garden Federation ${ }^{5}$ has adopted a "Gardening and Environment Charter" that recommends properly managing organic material, reducing water consumption, choosing adequate plantations, ceasing the use of chemicals, developing natural fertilization, reducing waste, encouraging the reproduction of the garden fauna, and creating more aesthetic gardens. This Charter aims to develop better knowledge on natural mechanisms that will foster the implementation of pro-environmental cultural practices. Several factors might force change: control over gardeners' practices and frequent reminders about the new regulations, education and training, and also network diffusion thanks to neighbourhood relationships and to the arrival of a more educated and environment-aware population within the plots. At a broader level, the Federation aims at participating in citizens' education on sustainability by opening its allotments to the public more often. Because the existence of allotments is often frail due to urban pressure, environmental concerns provide them with a new legitimacy. 


\section{Empirical material}

This paper is based on a 12-month research project that began in September 2011. It consisted of ethnographic observations within allotments and multiple informal interviews with gardeners (for methodological insights, see Bruneteaux and Lanzarini 1998). Empirical material was collected at a particular site, which we will refer to as "Bel Air". This site was chosen because it existed long before the introduction of explicit environmental rules (it was created at the end of the 1960s). The Bel Air allotment is situated in the Parisian suburbs, in an area formerly dedicated to tree nurseries (Phlipponneau 1956). The area is now totally urbanised and socially constituted of manual workers, employees, or lower-middle classes (Préteceille 2003). Bel Air is composed of more than a hundred plots, each around 100 square metres. Pumps connected to the public water system are at the gardeners' disposal at several points on the site. It is a traditional site in the sense that the aspect of plots is not standardised and that it is closed to the public ${ }^{6}$.

At Bel Air, we met 19 gardeners. We observed them undertaking different activities in the plot during different seasons throughout our fieldwork period (from October 2011 to July 2012). We met with gardeners alone or with some visitors. We purposively selected our interviewees to represent social characteristics including age, gender, and education. Neighbourhood relations in the allotment guided our contacts. Gardeners knew our institutional attachments to the French National Institute for Agricultural Research ${ }^{7}$, but most of them had no clear idea of what it meant and 
considered us variously as a journalist, a photographer, and even police officer. In the interviews, we asked gardeners to tell us about their plot (its kitchen garden section, its shed, etc.), their gardening practices, their learning processes, the allotment's context (rules, social relations with neighbours, etc.), their food consumption practices, and their domestic and leisure activities.

We chose not to impose the theme of sustainability on the discussions in order to avoid influencing gardeners' actions and discourses. Indeed, analysing sustainable lifestyles is not only a question of observing new ways of doing; it also requires taking into account existing practices compatible with environment. In a recent paper, Bente Halkier (2009), following Warde (2005), explains that environmentalised food consumption can be analysed either as a specific practice or as an aspect of other types of practice. On the first assumption, environmentalised food consumption can be considered as a practice in itself because other everyday practitioners recognise it as a specific practice. On the second, it can be seen as part of broader food practices that may dovetail with environmentally friendly food consumption (such as consuming for pleasure, taking care of one's health, planning food practices). Halkier suggests that both conceptions contribute to an understanding of sustainable food consumption, and we follow this approach.

We should précis our discussion of Bel Air with a comment on its conflictual formal status. The site has officially been run by a national allotment organisation since the 1960s, but a local association has been contesting this authority for several years. The conflict is principally over the allotment's formal possession. Both structures claim 
responsibility for the site and request respect of their separate specific rules. The national organisation requires an internal rule be followed. At several locations in Bel Air, the national organisation displays explicit rules for pro-environmental gardening (gardeners are informed that their practices are monitored by a local supervisor). The local association does not have the administrative legitimacy to lay down an internal rule, but subscribers are requested to comply with the activities of the association, which imply ecological matters. Indeed, in order to obtain control of the allotment, the association promotes the site as a natural area contributing to the conservation of biodiversity and the protection of urban quality of life. For most gardeners, this conflicting leadership is confusing and some pay dues to both structures to ensure that they will keep their plot whatever happens.

\section{Results: Three ideal types of gardeners}

We analysed the meaning of gardening for gardeners by considering on the one hand, how they dealt with their plots and what they represented to them, and on the other hand, how they talked (or did not talk) about sustainability, ecology, or the environment. Adopting a grounded theory approach (Glaser and Strauss 1967), we used a typological analysis to describe three ideal types of gardeners distinguished by the different degrees to which they have integrated practices and norms on sustainability. 
Ideal type 1: "A natural place": Pro-environmental gardening as part of an existing environmentally friendly lifestyle

For this ideal type of gardener, perceptions of the garden are congruent with national initiatives, since their practices are oriented to nature and human health protection. They demonstrate a "routinized reflexivity", which means that the gardeners are engaged positively in doing good for the environment, and this practice has become routinized (Halkier 2009). The gardeners are concerned about sustainability and practise their commitments to sustainability both in the garden and at home.

The gardeners pointed out the importance of eating fresh garden foods, which they considered tasty, but most importantly as healthy because no pesticides were used to produce them. They did not first consider their plot as a productive place, but rather as a natural space in the sense of "wild nature" as opposed to "domesticated nature" (Clayton 2007). In their plots, there were no dedicated places for picnicking or rest (sometimes just a little table and a chair). They barely mentioned their gardening techniques. Even though they dedicated considerable work to their plots, they nevertheless presented them as natural spaces separate from the effects of human intervention. Further, they differentiated "natural" from "organic" on the basis that the latter can be industrialised and such cultivations do not grow at their "natural" rhythm. Intrinsically linked with their interest in nature was their interest in protecting and conserving wild life (by using no pesticides), plant varieties (by collecting seeds), and human health (by eating fresh organic foods). Regarding their 
food consumption practices, they did not mention overproducing, but they did preserve surplus vegetables. They would sometimes deep-freeze, but did not insist on these preservation techniques. They preferred to keep some of their potatoes or apples in a shed or at home (on the windowsill or on the balcony). They were more interested in eating fresh seasonal products and expressed little interest in eating summer vegetables during winter. They mentioned buying seasonal organic food for their everyday consumption. They attended weekly markets and organic food shops to buy food as well as other items such as cleaning products or cosmetics.

The social characteristics of these gardeners correspond with current knowledge of the social stratification of sustainable behaviours (Hoibian 2010). These gardeners are highly educated and occupy, or occupied, stable occupational positions. Many lived at a distance from Bel Air in other suburban districts. All reported long-term involvement in gardening in an urban context and mentioned the importance of a familial tradition. They learned from their parents or grandparents, and had spent time in family houses in the countryside. Interestingly, their representation of plots as natural places was compatible with the relatively limited time they spent organising their plots. They were still working or were active retirees, and reported familial duties and associative or leisure activities that often carried responsibilities. They made frequent but largely unplanned visits to their plots. Their activities changed flexibly from week to week. They did not presume a duty of care for their gardens and were not concerned over being late in carrying out seasonal work. They would 
request some help from other gardeners, but restricted their relationships in Bel Air to other gardeners similarly interested in the perception of the plot as a natural place.

A gardener whom we will call "Hélène” illustrates this first ideal type. Hélène’s gardening experience demonstrates an interest in a natural space where environment and health are protected, and framed by a lifestyle committed to ecology. Hélène’s plot is highly hedged; it is almost impossible to see inside from Bel Air's paths. Her plot is connected to her father's adjacent plot. She has been cultivating in Bel Air with her father, who had a plot from the very beginning of the allotment, since she was nine years old. Now 48 years old and working as a cost controller in a large transport company, Hélène often uses the verb "to naturalise" and is satisfied that her garden is never the same from one year to the next. She allows plants to grow wherever their seeds have fallen. She sees her garden as a friendly place for biodiversity. She cares for rare species of animals and cultivates vintage (or rare) varieties of vegetables and flowers. It is also a friendly place for her and her father because it enables them to maintain good physical and mental health through the activity of gardening itself as well as through consumption of the garden's produce. Hélène recycles small containers previously used to hold organic products (yogurt or cream containers) for holding small tools or storing seeds that she stores in her shed. Indeed, she buys almost only organic food. She lives close by and walks to the allotment. Hélène is involved in several associations, but in her principal role as President of the local association of Bel Air has been struggling for around five years for the site to be recognised as a natural area in the local urban plan. If she wins 
management of the site, Hélène would like to be more select in choosing allotment members in order to avoid, she says, social problems.

Generally this first ideal type represented a lifestyle coherent with concerns over sustainability. Their interest in gardening was intrinsically linked with their concerns for nature, environment, and health, and reflected in their consumption practices. Gardening may be considered as part of their “ordinary resistance” (Dobré, 2002). This first ideal type appeared concerned with sustainability, but this did not appear to be the case with the second ideal type.

Ideal type 2: "Gardening for pleasure": Pro-environmental gardening as a technical skill

In this second ideal type of gardener, mechanisms of change are clearly visible. Gardeners were implementing new pro-environmental gardening practices, and their gardening activities were also the origin of new practices at the domestic level. However, this ideal type shows that the diffusion of social norms on sustainability does not parallel the diffusion of pro-environmental practices.

For this ideal type, the plot was considered a place of self-production, where fruits, vegetables and flowers were produced through personal labour. The idea of selfproducing is important because cultivating is considered a technical activity that requires investments of personal time and skills, from which much pleasure can be derived. These gardeners came regularly to the allotment and dedicated time to 
gardening activities. They demonstrated considerable reflexivity on techniques. Gardeners insisted on what, and how, they performed. They followed instructions on when, where, and how to plant, and often recorded what they had done using calendars. They mentioned gardening magazines (print ${ }^{8}$, radio, or television ${ }^{9}$ ), books, the Internet, and neighbours as sources of information on gardening techniques. In fact, they turned out to be on good terms with people concerned with sustainability and ecology (inside the allotment as well as outside), with whom they had regular contact and received advice or help (whether they asked for it or not).

They were learning how to maintain a garden by themselves and in so doing were learning ecological techniques taught by their neighbours or from magazines they read. They were also much more aware of these types of abstract guidelines than of the explicit ecological rules of the allotment. Making one's own fertilizers or pesticides constituted interesting examples, since gardeners of this second ideal type were receptive to these practices, which they presented both as efficient and ecological and as requiring efforts and skills (we noticed for instance their involvement in properly managing the making of their own compost, or of nettle slurry). Nevertheless, they continued to purchase commercial fertilizers, but always those labelled "organic". They also paid attention to gardening materials, and equipped their gardens with composting bins, new rain barrels, or specific tools (such as the grelinette $^{10}$ ). Their gardening practices also introduced some specific changes in consumption practices in the domestic sphere. They liked eating garden produce fresh and expressed a desire to prepare good dishes with them that required spending 
time in the kitchen or learning new recipes. Moreover, preservation techniques were developed and presented as ways to maximise and extend the benefits of garden production. Gardeners of this second ideal type tested preservation techniques, but mostly for deep-freezing fresh vegetables. Apart from food consumption practices, all were making their own compost and expressed a new commitment to recycling food waste and recycling materials such as cups that could be used in the garden for seedlings. On the whole, their interest in self-production translated from the garden to the home.

Their demonstrated interests in doing things for themselves, learning, and improving their abilities may be expressions of their social trajectories. While they had lived long years in urban areas, many were originally from rural backgrounds and had observed their parents and grandparents, artisans or farm-workers engaged in kitchen gardening in the countryside. Even though that background may constitute an advantage (following Grignon and Grignon 1980), they themselves saw their rural knowledge of gardening as very different from what they were doing in Bel Air. They rejected suggestions of having prior experience in urban gardening, which for them meant cultivating different varieties in a single small plot. They distanced themselves from their rural origins all the more so since they felt they had succeeded in social ascension. They all had low levels of education, but had experienced stable and satisfying careers in which they had progressively gained responsibilities. Interestingly, gardeners of this second type often mentioned the schools and/or professional trajectories of their children and talked of their achievements. 
In what might seem contradictory behaviour in this group, pro-environmental practices were evidently in circulation, but we did not observe the emergence of any corresponding environmental concerns. First, they had introduced some proenvironmental techniques in the garden, such as collecting water or favouring light digging, that they presented as more convenient (in the sense that the techniques are less physically demanding). Second, even though they produced their own pesticides using natural methods, they used chemical inputs when the former were insufficient and when they needed to protect their self-produced foods (observations of their plots showed that they used anti-slug granules abundantly). Third, some environmental practices such as sorting domestic waste in the plot (apart from food waste that went into a composting heap) and limiting public water use after a picnic or a barbecue, were not observed at all. Fourth, they considered foods coming from the garden differently. They distinguished tasty and healthy food from food not as tasty and grown using chemical products, but convenient for providing the family with daily food.

During fieldwork, we interviewed a gardener couple "Christian" and "Sylvie”, who reflect this second ideal type. Their gardening experiences underscore the importance of self-production. Christian, aged 50 years, worked as a driver. His wife, Sylvie, also 50 years old, worked as a home health-care worker with the urban district council. They both came from a rural region of France, where their parents had worked on farms. Christian said he started at the bottom of the social scale, but now has responsibilities and professional autonomy. They had enjoyed access to a plot for 
four or five years, thanks to Hélène, the President of the local association, who was their immediate neighbour. Christian comes to the allotment every day to see if everything is in order and to relax after work. He longs for garden work. For instance, he planted tomatoes at the end of March because he obtained plants at a cheap price in the supermarket Lidl (situated in the neighbourhood) and felt like planting them, even though it was too early in the season. He justified his decision as an opportunity to test some techniques using a cold frame. The equipment at Christian and Sylvie's plot, which included two brand-new plastic composting bins they bought at Lidl for a good price, also showed their interest in techniques and materials. They paid much attention to keeping the bins clean and placed them on two slabs of stone to keep them off the ground. Both Christian and Sylvie enjoyed explaining how they use them. The compost in one bin is ready to use, while waste goes into the other, which is in the process of composting. They have advantages of no odour, an access door on the top and another at the bottom for ease of use. Sylvie and Christian enjoyed preparing good meals from their garden harvest and praised deep-freezing as the best way to preserve the taste of almost all vegetables. At the same time, Sylvie often bought foods that are easy to prepare for daily meals. Christian expressed disappointment that amateur gardeners are now forbidden to buy anti-germination products. He had lost all his potatoes the previous winter, which had frozen in his shed, and he regretted being unable to store them at home using anti-germination products. 
In this second ideal type of gardener, we have highlighted the discontinuity between the diffusion of practices and the diffusion of norms. We have not pointed out forms of resistance, but rather a mechanism of change demonstrating that the performance of practices can be associated with completely different meanings. Therefore, the expected outcomes of the introduction of pro-environmental practices, such as education to eco-citizenship and more sustainable behaviours in daily life, may not be matched.

Ideal type 3: "A privatised garden in a shared space": Pro-environmental gardening as a new local rule to respect

In this ideal type of gardener, new pro-environmental practices are barely implemented since an existing routinized use of the garden is not compatible with sustainability objectives. When new practices are introduced, they are not integrated with pro-environmental norms. We also observed some forms of resistance.

Gardeners here match analyses of popular gardening at the end of the $20^{\text {th }}$ century (Pluvinage and Weber 1993; Weber 1998). On the one hand, the plot is seen as a privatised place - as an outside room of the house and more so if it is situated at a close distance. Men were the main carers of the kitchen garden. They said they came to the allotment daily because there was always something to work on. For them, the garden must be above all clean (no leaves or weeds on the regular paths) and produce beautiful vegetables of proper size, colourful skin, and untouched by pests. These 
gardeners had had access to their plots for many years and had learned how to cultivate a garden by working with their parents in rural areas. Their professional or personal situations were often socially fragile. They experienced precarious employment situations and health problems in particular, and they presented their garden as a place to ease some of their everyday hardship. The plot was also described as a convivial place visited by family members, friends, and neighbours. Barbecues or picnics were held during spring and summer. Gardeners praised good social relations within the entire site, but were implicated more directly in close garden neighbourhood relations. Gardeners knew each other and often each other's families very well, knew what others were doing in their plots, spent time talking with one another, and went inside their neighbours' plots. They exchanged advice, plants, seeds, tools, and machines with one another. For instance, at the approach of the end of the winter, we recorded conversations between gardeners regarding the best seeds to buy and where to find them. Each gardener had an opinion on the characteristics of different brands of seeds and recounted from their personal experiences how many seeds germinated the previous year, and the quality of the crop.

New pro-environmental practices, such as preserving seeds or bulbs from one year to use the next, collecting water, and stopping the use of pesticides and chemical fertilizers, appeared as local rules that should be respected along with the other rules of the allotment (such as not selling the garden's harvest or breeding animals). Knowledge of the environmental rules essentially came from discussions with other 
gardeners and observations of their practices. We observed imitation processes, particularly in material use of garden equipment. In Bel Air, increasing numbers of plots were equipped with new composting bins or rain barrels. This equipment was clearly visible. Interestingly, gardeners of this third ideal type, who preferred taking their water from the water pump (many had systems of pipes to reduce the distance to their garden) and who did not systematically make their own compost, felt induced to at least take an interest in them, and in some cases to equip their own garden. However, these imitation processes had marginal effects. These gardeners identified the growth of garden vegetables and the presence of birds or animals in their plots as natural. Even though they praised these natural aspects, their use of chemical inputs was clearly expressed. Chemical inputs were presented as more efficient in preserving the aesthetic of the garden and the quality of the crop. Moreover, their opinions were reinforced by the routinized practices of other gardeners, such as exchanging $^{11}$ plants that must be beautiful and strong, or exchanging fertilizers that must be efficient. To legitimate their positions, they developed sceptical discourses on organic practices. For example, they claimed they would use only a few drops of chemical, while farmers would use much larger quantities on their fields, or that chemical fertilizers only contain elements that exist in nature.

With regard to their food-consumption practices, these gardeners put at some distance the idea of a nourishing garden. In addition to providing them with quantities of vegetables, the garden provided them with good food that was especially good for meals during summer. Preservation techniques allowed them the continued pleasure 
of eating garden foods. They argued that preserving was used to keep taste rather than to supply quantities over long periods and maintained that they did not produce enough food to preserve. They continued to buy vegetables at the supermarket or at the market, even during summer. More generally, choosing and purchasing products from shops, markets, and supermarkets were important for them. Interestingly, gardeners of this third ideal type did not mention many aspects of their food consumption behaviours apart from their garden food consumption. This may be explained by the fact that they distinguished clearly between the plot as both private and social and other domestic places or activities, which are only private.

We interviewed "George" and "Françoise", who particularly illustrate the combination of a private use of the plot with a social interest in a shared space. George, aged 66 years, was a retired electrician with good neighbourhood relations in Bel Air. He met his 68-year-old wife, Françoise, here. She had worked in a drycleaning business in a wealthy district of Paris and still occasionally worked for them. George had many occupations in the past that he learned on the job. To earn more money, he worked with Françoise as home-sitters three times a year. These periods represented holidays for them. Françoise and George lived at a very close walking distance to Bel Air and considered their plot as a home garden. George said that they spent all their weekends there during the summer and frequently organised picnics with friends. He told of a memorable moment when there were 15 guests around their garden table. For George, the plot must above all look like a welcoming place and had many rosebushes as important aspects of the aesthetic of the plot. George used 
chemicals on his rosebushes and was convinced that nothing else was more efficient. He showed us his chemical products the first time we met. By contrast, he did not know what to say about his cultivations. He repeated many times, "there you are, that's a garden; you plant and it grows," and "you should come during the summer ... you should come during the weekend", which suggests that the site was not interesting to George without its gardeners. He was very interested in what his garden neighbours were doing and often commented on them. For instance, he made fun of a neighbour who cultivates her garden very slowly and takes care of any worms she finds. However, he has good neighbourhood relations in the site. He explained that he was given a rain barrel the previous year, but prefers to use the water pump. Similarly, he was trying to make his own compost because he knew that everybody else did it. He was curious, but cautious. George constructed a wooden composting bin, but made it small on purpose; for the first year, he would test it only on his tomato plants and did not want it to take up too much space.

In this third ideal type of gardener, even though some practices circulate, they remain marginal. It demonstrates the difficulty in implementing new practices in a context where already routinized practices are established and regularly reproduced with no interest in change. At the same time, we observed the performance of routinized ways of dealing with the plot that were incompatible with sustainability objectives, as well as resistance to new practices that would modify existing practices. Above all, we observed the social links created through these practices. Nevertheless, in Bel Air, the resistance of popular gardeners to change does not lead to direct conflict because 
control over conformity to rules is not strict, and also because the persons in charge of the site, belonging to the national organisation as well as to the local association, advocate for slow and progressive change, especially for the older gardeners.

\section{Conclusion}

Our paper has questioned the integration of sustainable norms and practices by individuals who are frequently exposed to pro-environmental recommendations because of their kitchen gardening activities. We focused on changes in gardeners participating in an allotment since they are more subjected to legal and social controls. We have demonstrated that all gardeners, de facto, implement ecological gardening practices. On the basis of our fieldwork, we maintain that social contacts, understood as discussions with others as well as observations of what others do, are key vectors for the diffusion of pro-environmental practices. Because allotments gather many gardeners within a close space, they seem to be the appropriate places to introduce more sustainable behaviours (Holland 2004). Gardeners in Bel Air do have good social relations. The first and third ideal types of gardeners we have identified correspond to existing groups with internal sociability. There is limited interaction between them and cautious expressions of mutual disapproval that are particularly visible during the annual competition for the most beautiful garden, organised by the local district. Gardeners of the third ideal type, who usually win this competition, do not understand how some gardeners (from ideal type 1) dare to compete with gardens 
they see as "messy" in comparison with their straight rows of cultivation. In contrast with ideal types 1 and 3, gardeners from ideal type 2 are not particularly concerned with internal sociability, but rather have particularly good neighbourhood relationships with gardeners from ideal type 1 , which, as we have seen, is important for the diffusion of ecological practices.

However, we have argued that practices circulate better than norms because gardeners do not introduce particular concerns for the environment in parallel with their implementation of pro-environmental practices. We have shown that ideal type 2 , which introduces most of the new practices, is at a distance from the emergence of an environmental concern, since their interest in nature is not as important as their interest in manual, self-produced activity. We can see that practices may not hold the same meaning for associative rulers and for gardeners. They can be reinterpreted. In the case of ideal type 2, there is no emergence of a concern for environment, nor of a reflexivity (Halkier 2009), that might generate deeper changes regarding daily practices. We concentrated on the link between garden and food consumption, but it would be interesting to observe other spheres of everyday life to strengthen our argument.

There are some limits to our study. First, since we did not interview all the gardeners of Bel Air, our typology may not reflect all possible mechanisms. Second, a comparison with a more recent site would be interesting, since we could then formulate the hypothesis that, in this other site, gardeners may feel more committed to pro-environmental gardening. However, focusing on sustainability and 
concentrating on a traditional site, we have differentiated gardeners from an original point of view against the existing literature. The first ideal type fits with what we know about sustainable consumers who display coherent lifestyles and interest in producing their own vegetables naturally as well as in protecting the environment. The third ideal type corresponds to the characteristics of popular gardening. The second ideal type is more heterogeneous than the other two regarding the way it deals with plots (some see their plot as a convivial place, as with ideal type 3) and their relation to sustainability (some are more involved in ecological actions, like ideal type 1). We recruited them because of their interest in self-production, which differentiates them from other gardeners and is clearly linked with their implementation of sustainability practices. However, this second ideal type might illustrate a transitional stage and gardeners might progressively converge from one of the two other ideal types, with, very likely, a changing relation to sustainability.

\section{Acknowledgements}

This research was funded by a postdoctoral fellowship from the region Ile de France (programme DIM ASTREA). Results were presented at the team seminar of food sociology, INRA ALISS UR 1303 (June 2012, Paris), at the XIII World Congress of International Rural Sociology (July-August 2012, Lisbon), and at the interim meeting of Sociology of Consumption Network of the European Sociological Association (September 2012, Berlin). The author thanks participants for their comments. The 
author would also like to thank Séverine Gojard, Florence Weber, François Jeannet, Sophie Dubuisson-Quellier, Marie Plessz, Ana Perrin-Hérédia and Anaïs Malié for their contribution to different stages of this research.

\section{Notes}

${ }^{1}$ Le Grenelle de l'environnment.

${ }^{2}$ Products are currently freely sold in supermarkets or specialist shops, and choice left to the individual consumer.

${ }^{3}$ During the period of Les Trente Glorieuses (1945-1973), as the working class gained access to private housing, the demand for allotments declined and tended to disappear under urban pressure.

${ }^{4}$ Jean-Noel Consales (2000), for the city of Marseille, underscores the reduction in working class participation as well.

${ }^{5}$ La Fédération Nationale des Jardins Familiaux et Collectifs.

${ }^{6}$ In our case, the site is supposed to be closed since there are several locked gates, but these gates are usually open. However, apart from gardeners and their visitors, people generally do not walk on Bel Air's paths, which do not look like urban promenades (they are narrow, muddy, and disorienting).

${ }^{7}$ Institut National de la Recherche Agronomique (INRA) 
${ }^{8}$ Above all the magazine Rustica.

${ }^{9}$ Several gardeners mentioned the programme Silence ça pousse (broadcast on France 5 every Wednesday evening).

10 The grelinette (broadfork) was invented by Mr Grelin in the 1960s for protecting the ecosystem while digging. This tool is often used in organic gardening.

${ }^{11}$ Exchanges can introduce money.

\section{References}

Alaimo, K., E. Packnett, R.A. Miles and D.J. Kruger (2008) Fruit and vegetable intake among urban community gardeners. Journal of Nutrition Education and Behavior 40(2) pp. 94-101

Alaimo, K., T.M. Reischl and J.O. Allen (2010) Community gardening, neighborhood meetings, and social capital. Journal of Community Psychology 38(4) pp. 497-514

Barrault, J. (2009) L’usage des pesticides par les jardiniers amateurs. Responsabilité et environnement. Pp. 227-236 in M. Dobré and S. Juan eds, Consommer autrement. La réforme écologique des modes de vie (Paris: L’Harmattan)

Bruneteaux, P. and C. Lanzarini (1998) Les entretiens informels. Sociétés contemporaines 30 pp. 157-180

Cabedoce, B. and P. Pierson (1996) Cent ans d'histoire des jardins ouvriers. 18961996, La Ligue du Coin de Terre et du Foyer (Grâne: Créaphis)

Caillavet, F. and V. Nichèle (1999) Autoconsommation et jardin. Arbitrage entre production domestique et achats de légumes. Économie rurale 250 pp. 11-20

Campbell, C. (2005) The craft consumer: culture, craft and consumption in a postmodern society. Journal of Consumer Culture 5(1) pp. 23-42 
Clayton, S. (2007) Domesticated nature: motivations for gardening and perceptions of environmental impact. Journal of Environmental Psychology 27 pp. 215-224

Consales, J.N. (2000) Les jardins familiaux marseillais: laboratoires territoriaux d’une agriculture urbaine en Méditerranée. Méditerranée 95(3/4) pp. 81-88

Constantine, S. (1981) Amateur gardening and popular recreation in the $19^{\text {th }}$ and $20^{\text {th }}$ centuries. Journal of Social History 14(3) pp. 387-406

Dobré, M. (2002) L'écologie au quotidien. Eléments pour une théorie sociologique de la résistance ordinaire (Paris: L’Harmattan)

Dubost, F. (1997) Les jardins ordinaires (Paris: L’Harmattan)

Gelber, S.M. (1997) Do-it-yourself: construction, repairing and maintaining domestic masculinity. American Quaterly 49(1) pp. 66-112

Girardin, P. (1994) Jardins familiaux, jardins privés... quand le mieux est l'ennemi du bien. Le courrier de l'environnement de l'INRA 23

Glaser, B.G. and A.L. Strauss (1967) The discovery of grounded theory: strategies for qualitative research (London: Weidenfeld and Nicolson)

Gojard, S. and F. Weber (1995) Jardins, jardinage et autoconsommation alimentaire. INRA Sciences Sociales 2

Grignon, C. and C. Grignon (1980) Styles d'alimentation et goûts populaires. Revue Française de Sociologie 21(4) pp. 531-569

Guyon, F. (2008) Les jardins familiaux aujourd'hui: des espaces socialement modulés. Espaces et sociétés 134(3) pp. 131-147

Hale, J., C. Knapp, L. Bardwell, M. Buchenau, J. Marshall et al. (2011) Connecting food environments and health through the relational nature of aesthetics: gaining insight through the community gardening experience. Social Science and Medicine 72(11) pp. 1853-1863

Halkier, B. (1999) Consequences of the politicization of consumption: the example of environmentally friendly consumption practices. Journal of Environmental Policy and Planning 1(1) pp. 25-41

Halkier, B. (2009) A practice theoretical perspective on everyday dealings with environmental challenges of food consumption. Anthropology of food S5 Available at http://aof.revues.org/6405 Accessed 07 May 2012 
Hargreaves, T. (2011) Practice-ing behaviour change: applying social practice theory to pro-environmental behaviour change. Journal of Consumer Culture 11(1) pp. 79-99

Hoibian, S. (2010) Enquête sur les attitudes et comportements des Français en matière d'environnement (Paris: CREDOC)

Holland, L. (2004) Diversity and connections in community gardens: a contribution to local sustainability. Local Environment 9(3) pp. 285-305

Monédiaire, G. (1999) Agricultures urbaines et ville durable européenne. Droits et politiques $d u$ jardinage familial urbain en Europe (Limoges: Presses Universitaires de Limoges)

Phlipponneau, M. (1956) La vie rurale de la banlieue parisienne. Étude de géographie humaine (Paris: Armand Colin)

Pinçon, M. (1986) Autoproduction, sociabilité et identité dans une petite ville ouvrière. Revue Française de Sociologie 27(4) pp. 629-653

Pluvinage, M. and F. Weber (1992) Les jardins populaires: pratiques culturales, usages de l'espace, enjeux culturels. Éléments d'histoire et d'ethnographie. Report to the French Ministry for Culture (AO87FR107)

Pluvinage, M. and F. Weber (1993) Le jardinage ouvrier: ressource alimentaire et affirmation de soi. Cahiers d'Économie et Sociologie Rurales 27 pp. 96-122

Préteceille, E. (2003) La division sociale de l'espace francilien. Typologie socioprofessionnelle 1999 et transformations de l'espace résidentiel 1990-1999. Report to the public works department of the region Ile de France. Available online at http://halshs.archives-ouvertes.fr Accessed 08 September 2011

Robbins, P. and J.T. Sharp (2003) Producing and Consuming Chemicals. Economic Geography 79(4) pp. 425-451

Rumpala, Y. (2009) La "consommation durable" comme nouvelle phase d'une gouvernementalisation de la consommation. Revue Française de Science Politique 59(5) pp. 967-996

Schupp, J.L. and J.S. Sharp (2012) Exploring the social bases of home gardening. Agriculture and Human Values 29(1) pp. 93-105 
Wakefield, S., F. Yeudall, C. Taron, J. Reynolds and A. Skinner (2007) Growing urban health: community gardening in south-east Toronto. Health Promotion International 22(2) pp. 92-101

Warde, A. (2005) Consumption and theories of practice. Journal of Consumer Culture 5(2) pp. 131-153

Weber, F. (1998) L'honneur des jardiniers. Les potagers dans la France du XX siècle (Paris: Belin)

Weber, M. (1976) Wirtschaft und Gesellschaft (Tübingen: Mohr Siebeck) 


\section{ALI SS Working Papers}

\section{2}

2012-06 Etilé, F., Teyssier, S. Signaling Corporate Social Responsibility:Third-Party Certification vs. Brands. Aliss Working Paper, 2012-06, septembre 2012, 40 p.

2012-05 Teyssier, S., Etilé, F., Combris, P. Social and Self-I mage Concerns in FairTrade Consumption: Evidence from Experimental Auctions for Chocolate. Aliss Working Paper, 2012-05, juillet 2012, 40 p.

2012-04 Brechet, T., Meunier, G. Are clean technology and environmental quality conflicting policy goals? Aliss Working Paper, 2012-04, avril 2012, 29 p.

2012-03 Fischbacher, U., Schudy, S., Teyssier, S. Heterogeneous Reactions to Heterogeneity in Returns from Public Goods. Aliss Working Paper, 201203, mars 2012, $38 \mathrm{p}$.

2012-02 Maurice, A. Que font les adolescents des programmes d'éducation alimentaire proposés aux niveaux national et local ? Aliss Working Paper, 201202, février 2012, $25 \mathrm{p}$.

2012-01 Bazoche, P. ; Bunte, F. ; Combris, P. ; Giraud-Héraud, E. ; Seabra-Pinto, A. ; Tsakiridou, E. Willingness to pay for pesticides' reduction in E.U: nothing but organic? Aliss Working Paper, 2012-01, janvier 2012, 16 p.

\section{1}

2011-06 Cardon, P. ; Gojard, S. La diffusion des recommandations nutritionnelles au regard des conditions de vie : comparaison enfance et vieillesse. Aliss Working Paper, 2011-06, octobre 2011, 23 p.

2011-05 Etilé, F. ; Teyssier S. Corporate Social Responsibility and the Economics of Consumer Social Responsibility. Aliss Working Paper, 2011-05, août 2011, 33 p.

2011-04 Allais, O. ; Etilé, F. ; Lecocq, S. Mandatory labeling vs. the fat tax: an empirical evaluation of fat policies in the French fromage blanc and yogurt market. Aliss Working Paper, 2011-04, juillet 2011, 43 p.

2011-03 Fischbacher, U. ; Föllmi-Heusi, F. ; Teyssier, S. Voluntary Standards and Coordination in Public Goods Games. Aliss Working Paper, 2011-03, avril 2011, 30 p.

2011-02 Etilé, F. Changes in the Distribution of the Body Mass index in France, 1981-2003: a Decomposition Analysis. Aliss Working Paper, 2011-03, avril 2011, 41 p.

2011-01 Chevet, J.M. ; Lecocq, S. ; Visser, M. Climate, Grapevine Phenology, Wine Production and Prices: Pauillac (1800-2009). Aliss Working Paper, 201101, janvier 2011, $13 \mathrm{p}$. 
2010-07 Plessz, M. ; Gojard, S. La consommation de légumes des ménages français : préparation domestique ou achats de produits transformés. Aliss Working Paper, 2010-07, octobre 2010, 24 p.

2010-06 Blanchard, P.; Huiban, J.P, Mathieu, C. The Dynamics of French Food Industries: Productivity, Sunk costs and Firm Exit, Aliss Working Paper, 2010-06, juillet 2010, $26 \mathrm{p}$.

2010-05 Chandon, P., Etilé, F. Comportements alimentaires et politiques de santé nutritionnelle. Prix, information, marketing quelles régulations ? Aliss Working Paper, 2010-04, mai 2010, 20 p.

2010-04 Chandon, P., Etilé, F. Marketing et économie des choix de consommation alimentaire en relation avec la santé : un bref état des lieux, Aliss Working Paper, 2010-04, mai 2010, 30 p.

2010-03 Lhuissier, A., Weight-Loss Practices among Working-class Women in France, Aliss Working Paper, 2010-03, avril 2010, 13 p.

2010-02 Clark, A.E., Etilé, F. Happy House: Spousal Weight and Individual WellBeing, Aliss Working Paper, 2010-02, avril 2010, 32 p.

2010-01 Giraud-Héraud, E., Grazia, C., Hammoudi, A. Hétérogénéité internationale des normes de sécurité sanitaire, stratégie des importateurs et exclusion des producteurs dans les pays en développement, Aliss Working Paper, 2010-01, février 2010, $44 \mathrm{p}$.

\section{9}

2009-05 Caillavet, F., Nichèle, V., Soler, L.G. Are Nutrition Claims an Adequate Tool for Public Health? Aliss Working Paper, 2009-05, juillet 2009, 21 p.

2009-04 Etilé, F., Jones, A.M. Smoking and Education in France, Aliss Working Paper, 2009-04, avril 2009, 55 p.

2009-03 Bruegel, M., Chevet J, M., Lecocq, S., Robin, J.M. On the Crest of Price Waves or Steady as She Goes? Explaining the Food Purchases of the ConventSchool at Saint-Cyr 1703-1788, Aliss Working Paper, 2009-03, avril 2009, 50 p.

2009-02 Bazoche, P., Combris, P., Giraud-Héraud, E. Willingness to pay for appellation of origin: results of an experiment with pinot noir wines in France and Germany, Aliss Working Paper, 2009-02, janvier 2009, 18 p.

2009-01 Lhuissier, A. "Faire régime": approches différenciées d'une pratique corporelle en milieu populaire, Aliss Working Paper 2009-01, janvier 2009, 19 p.

\section{8}

2008-10 Hammoudi, A ; Nguyen, H.H. ; Soler, L.G. Segregation and testing strategies for GM/ non GM coexistence in supply chains. Aliss Working Papes 2008010, octobre 2008. 31 p.

2008-09 Deola, C. ; Fleckinger, P. Pesticide regulation : the case of French wine. Aliss Working Paper 2008-09, octobre 2008, 23 p. 
2008-08 Lecocq, S. Variations in choice sets and empirical identification of mixed logit models: Monte Carlo evidence, Aliss Working Paper 2008-08, août 2008, 23 p.

2008-07 Giraud-Héraud, E. ; Hammoudi, A. ; Hofmann, R. ; Soler, L.G. Vertical relationships and safety standards in the food marketing chain, Aliss Working Paper 2008-07, juillet 2008, 30 p.

2008-06 Régnier, F.; Masullo A. Une affaire de goût ? Réception et mise en pratique des recommandations nutritionnelles, Aliss Working Paper 2008-06, juillet 2008, $51 \mathrm{p}$.

2008-05 Giraud-Héraud, E. ; Grazia, C. ;Hammoudi, A. Strategies for the development of brands in the agrifood chains, Aliss Working Paper 2008-05, juillet 2008, $34 \mathrm{p}$.

2008-04 Cardon, P; Gojard, S. Les personnes âgées face à la dépendance culinaire : entre délégation et remplacement, Aliss Working Paper 2008-04, Juillet 2008, 22 p.

2008-03 Allais, O. ; Bertail, P. ; Nichèle, V. The effects of a "Fat Tax" on the nutrient intake of French Households, Aliss Working Paper 2008-03, J uin 2008, 36 p.

2008-02 Etilé, F. Food Price Policies and the Distribution of Body Mass Index: Theory and Empirical Evidence from France, Aliss Working Paper 2008-02, J uin 2008, $52 \mathrm{p}$.

2008-01 Boizot-Szantaï, C., Etilé, F. Le prix des aliments et la distribution De I'Indice de Masse Corporelle des Français, Aliss Working Paper 2008-01, Mai 2008, $19 \mathrm{p}$. 